\title{
Kısmi Rezerv Sistemine Alternatif Bir İslam Ekonomisi Disiplini: Adil Ekonomik Düzen ve Para Arzı
}

\author{
An Islamic Economic Discipline as an Alternative to The Fractional Reserve System: \\ Just Economic Order and Money Supply
}

\author{
Sema Yaşar*
}

${ }^{1}$ Department of Economics, Sirnak University, Sirnak, Turkey

\begin{abstract}
Received: 24.05 .2021
Accepted: 30.07 .2021

This article was checked by intihal.net

\section{Öz}

Geçmişten bugüne kadar farklı türleri bulunan paranın bugün geleneksel bankacılık sistemi olarak da ifade edilen kısmi rezerv sistemi gereği üretilen ve banka parası olarak da isimlendirilen kaydi para türü son derece yaygın kullanım alanı bulmaktadır. Kısmi rezerv sistemi bankaya yatırılan mevduatın zorunlu karşılık olarak belirlenen bir miktarının bankada tutulup geriye kalan büyük kısmının ise faiz karşılığında kredi verilmesi suretiyle kaydi para oluşumu esasına dayanmaktadır. Bankaların ellerindeki mevduatların birkaç katı kadar para oluşturmalarını mümkün kılan bu sistemde yüksek enflasyon oranları, borçlanma, gelir dağılımı adaletsizliği, spekülatif hareketlere bağlı olarak ekonomik istikrarsızlık gibi pek çok sorunla karşı karşıya kalınmaktadır. İslam ekonomisinin bir disiplini olan Adil Ekonomik Düzenin para arzını üretime ve mal varlığına dayandıran para=mal ilkesi, kısmi rezerv sisteminin alternatifi olarak ortaya konulan bir para sistemidir. Bu çalışmada öncelikle genel hatlarıyla para kavramı incelenip, kısmi rezerv sisteminin tarihsel gelişimi değerlendirildikten sonra bu sistemin sebep olduğu makroekonomik sorunlara alternatif bir çözüm ortaya koyan Adil Ekonomik Düzenin para arzı ile ilgili yaklaşımı teorik olarak incelenmektedir.
\end{abstract}

Anahtar Kelimeler: Kısmi Rezerv Sistemi, Tam Rezerv Sistemi, İslam Ekonomisi, Adil Ekonomik Düzen

\section{Abstract}

The commercial bank money, which is one types of the money presenting different form from the past to the present, is produced by the partial reserve system referred to as the traditional banking system. It is also called bank money, and is widely used. The fractional reserve system is based on the principle of commercial bank money formation by keeping a portion of the lending deposits in the bank, which is determined as mandatory reserves rates, and granting loans in return for interest for the remaining portion. In this system, which enables banks to generate several times more money than their deposits, many problems such as high inflation rates, borrowing, unfair distribution of income, economic instability due to speculative movements are encountered. The system proposed as the most important alternative to the fractional reserve system today is the Just Economic Order, which is a discipline of the Islamic economy, connected to the full reserve system, offers equality of opportunity, promotes justice, bases the money supply on production, and has been developed specifically for the Turkish economy. In this study, first of all, the concept of money has been examined in general terms and the historical development of the fractional reserve system has been evaluated and the macroeconomic problems caused by this system and the alternative system proposed for these problems have been examined theoretically.

Keywords: The fractional reserve system, Full reserve system, Islamic economy, Just Economic Order

Yaşar, S. (2021). "Kısmi Rezerv Sistemine Alternatif Bir İslam Ekonomisi Disiplini: Adil Ekonomik Düzen ve Para Arzı", Journal of Academic Value Studies 7(2) (2021) 96-110().

*E-mail address: semayasar@sirnak.edu.tr 


\section{Giriş}

Pek çok farklı şekilde tanımı yapılan para, iktisatçılar açısından mal ve hizmet değişiminde kullanılan ve genel kabul görmüş herhangi bir şey olarak tanımlanmaktadır. Konuşma dilinde genel olarak nakit para kastediliyor olsa da banknotlar ve madeni paraların yanı sıra çekler ve dolayısıyla üzerine çek yazılabilecek olan mevduat hesapları ile kolayca nakde dönüştürülebilen vadesiz mevduatlar da para olarak kabul edilmektedir (Mishkin, 2007: 49). Paranın genel kabul görmesi oldukça önemlidir. Paranın en önemli özelliği olarak kabul edilen bu özelliğin geçerliliği ise devlet tarafından kabul edilebilirliğine bağlıdır (Lerner, 1947: 313). Bu durumda devlet tarafından kabul edilebilirliği yüksek olan paranın genel anlamda kabul görme olasılığının aynı oranda artacağı, devlet tarafından kabul edilebilirliği düşük olan paraların ise genel kabul görme olasıllğıının azalacağı yorumu yapilabilmektedir.

Paranın genel kabul görebilmesi için taşınabilirlik, dayanıklılık, bölünebilirlik, standart olma, taklit edilememe, homojenlik, zaman içerisinde değerini kaybetmeme gibi birtakım özelliklere sahip olması gerekmektedir. Üretilen paranın fiziksel anlamda dayanıklı olması, para olarak kullanılan nesnelerin ülkenin her yerinde nominal açıdan aynı değere sahip olarak standartlaşması, kolayca tanınması ve yapıldı̆̆ı maddenin her yerinin aynı değerde yani homojen olması, paranın devlet tarafından basılması sebebiyle taklit edilemez olması paranın genel özellikleri olarak değerlendirilmektedir.

Para ayrıca mübadele aracı olma, hesap birimi olma, değer ölçme ve saklama gibi fonksiyonlara sahiptir. Ancak bu fonksiyonların içerisinde en hayati öneme sahip olanı ise mübadele aracı olma işlevidir. Para bir meta değil sadece bir değişim aracıdır. Dolayısıyla paranın fiyatı olarak değerlendirilebilecek faizin de sıfır olması gerekmektedir (Çizakça, 2011: 13). Ekonomideki tüm piyasa işlemlerinde para mal ve hizmetler karşıllı̆̆nda bir değişim aracı olarak kullanılmaktadır. Ayrıca ekonomideki mal ve hizmetlerin değerini ölçmek için kullanılarak hesap birimi olma işlevine sahip olmaktadır. Para zaman içerisinde alım gücünün muhafaza edilmesini sağlayacak değer saklama fonksiyonuna sahiptir (Mishkin, 2007: 50-52).

Tarihsel süreç göz önünde bulundurularak değerlendirildiğinde paranın mal para, temsili para ve kaydi para olmak üzere temelde üç farklı çeşidinin olduğunu söylemek mümkündür. Mal para eski çağlarda mal ve hizmet alışverişlerinde değiş tokuş yapabilmek amacıyla para yerine kullanılmakta iken sonraki yıllarda altın ve gümüş mal para olarak kullanılmıştır. Altın ve gümüş paraların elde tutulmasının güvenli olmadığının düşünülmesi ile temsili para gündeme gelmiştir. Sertifikalar, banknotlar, kağıt paralar ise temsili para olarak kullanılmışlardır. Para çeşitleri içerisinde en önemlilerinden biri olan banka parası olarak da isimlendirilen kaydi paradır. Bankacılık sektörünün devreye girmesi ile beraber gündeme gelen kaydi para diğer para türlerine kıyasla maddi bir para olmayıp banka hesaplarında yer alan mevduatın hesaptan hesaba aktarılması yolu ile söz konusu mevduat miktarının birkaç katı kadar banka parası oluşturulması ile elde edilmektedir.

Para arzı süreci değerlendirildiğinde dört temel faktörden bahsetmek mümkündür. Bu faktörlerden ilki bankacılık sistemini denetlemekle görevli olan ve para politikasından sorumlu olan merkez bankasıdır. İkincisi kurumlardan ve bireylerden mevduat kabul eden ve kredi veren kurumlar olarak nitelendirilebilen bankalardır. Bankalarda mevduatlarını tutan birey ya da kurumlardan oluşan mevduat sahipleri üçüncü faktör iken bankalardan borç alan bireyler veya kurumlar ise dördüncü faktörü oluşturmaktadır (Mishkin, 2007: 333).

Bugün var olan para türleri merkez bankası tarafından oluşturulan nakit paralar ile merkez bankasının fiziki olarak basmamasına rağmen kayıtlarında görünen, sadece bankaların karşılıklı ödemelerde kullanmış oldukları kaydi para olarak adlandırılan rezerv hesaplarından oluşmaktadır. Nakit paraların fiziki olarak varlığı söz konusu iken kaydi paralarda fiziki anlamda bir parasal varlık söz konusu değildir. Fiziki anlamda bir parasal varlığın olmaması ve aynı zamanda bu anlamda bir para arzının gerçekleşiyor olması ise ekonomik anlamda önemli sorunların doğmasına neden olmaktadır. Bu sebeple bu çalışmada öncelikle kısmi rezerv bankacılığı sitemi ve kaydi para oluşumu ile kısmi rezerv bankacilığı sisteminin ekonomi üzerindeki olumsuz etkileri incelenmektedir. Bu problemlere çözüm önerisi olarak tam rezerv sistemi ve İslam ekonomisinde para arzı konusu incelenip ardından İslam ekonomisi özelinde Adil Ekonomik Düzen ve para=mal ilkesi değerlendirilmektedir. 


\section{Kısmi Rezerv Bankacılığı ve Kaydi Para Oluşumu}

Modern bankacılığın temelleri 17. yüzyılın ortalarında İngiltere'de atılmıştır. Sarraflık faaliyetleri ile başlayan süreçte sarraflar müşterilerin tasarruflarını emanet olarak alıp karşılığında tasarruf sahibine bir makbuz vermekte, söz konusu makbuzla herhangi bir tarihte sarraftan yatırılan tutar talep edilebilmektedir. Zamanla sarraflar yatırılan mevduatın uzun süre geri çekilmediğini fark etmişler ve kendilerinin teminat olarak verdikleri makbuzların piyasada mal ve hizmet alımı karşlığında kabul edildiğini görmüşlerdir. Bu durumda bankadaki paranın atıl vaziyette durduğunu ve söz konusu mevduatı borç talep edenlere kredi olarak vermenin daha avantajlı olduğunu düşünmüşlerdir. Ancak mevduat sahibinin makbuz karşılığında geri ödeme taleplerini karşılayabilmek adına bankada belirli bir oranını bulundurmaları gerektiği kanaatine varmışlardır. Tasarruf sahipleri tarafından yatırılan mevduatın belirli bir oranının zorunlu karşılık olarak merkez bankasında tutulup geri kalan kısmının kredi olarak verildiği bu sistem kısmi rezerv sistemi olarak adlandırılmaktadır (Diwany, 2011: 61-62).

Modern bankacılık sistemi olarak da adlandırılan kısmi rezerv bankacılığı sisteminin başlangıcı sarrafların sadece kendilerine emanet olarak bırakılan mevduatlar karşılığında değil aynı zamanda kredi almak isteyenlere de aynı senetleri vermeleri ile başlamışıı (Yılmaz, 2020: 52-53). İnsanların açgözlülüğü, yetersiz düzenlemeler, hükümetlerin mali ihtiyaçları gibi pek çok nedenle beraber kısmi rezerv bankacıllı̆̆ sistemine geçiş sağlanmıştır. Kısmi rezerv bankacılığının ürettiği tüm kazanılmış menfaatlerin devamlılığını sağlayabilmek adına yeterli yasal zemin oluşturmak oldukça önemli olduğu için söz konusu sistemi haklı çıkarmayı amaçlayan yasalar formüle edilmiştir (Huerta de Soto, 2020:115-116).

Neo-Klasik iktisadi yaklaşımın temellerini atmış olduğu kısmi rezerv bankacılığında paranın oluşturulması öncelikli olarak bankaların kredi verebilmeleri için belli bir miktar nakit yatırılması, kredi alanların aldıkları krediyi harcamaları, harcamaya konu olan mal ve hizmetleri satanların da aldıkları parayı tekrar bankaya yatırması gerekmektedir (Yılmaz, 2020: 57). Bugün geçerli olan kısmi rezerv bankacıllğının devamı ancak bu şeklide sağlanabilmektedir.

Paranın içeriği, kısmi rezerv bankacıllğ̆ı ile beraber bankalar içi ve bankalar arası mevduat akışının gerçekleşmesi ile son derece değişikliğe uğramıştır. Para artık değerli madenlerden üretilmemekte bankaların taşıdığı mevduatlar ve rezerv gibi belirli yükümlülüklerin toplamını temsil etmektedir. Para arzı ise önemli ölçüde kaydi para olarak adlandırılan aslında görünmeyen paradan oluşmaktadır (Ferguson, 2020: 47). Para arzı merkez bankalarının kontrolünde olmakla beraber kağıt para basımı merkez bankaları tarafından gerçekleştirilmekte iken bankalar ise kısmi rezerv bankacıllı̆ı gereği kaydi para üretmektedirler.

Para arzı konusunda literatürde iki farklı görüş bulunmaktadır. İlk görüş olan para ekolüne (currency school) göre para arzı sadece devlet tarafından gerçekleştirilmelidir ve bir altın standardı veya fiyat düzeyi kuralına bağlı olarak para arzına izin verilmelidir. Ayrıca bankaların para arzı görevi ile finansal aracılık görevlerinin birbirinden ayrılması gerektiğini ifade eden para ekolünün bu görüşü $\% 100$ rezerv sistemi olarak ifade edilebilecek olan tam rezerv sisteminin temelini oluşturmaktadır. Para arzı konusundaki diğer görüş olan bankacılık ekolü (banking school) ise daha katı kuralları benimseyen para ekolünün aksine sağduyu ve esnekliği tercih etmektedir. Çeşitli parasal kümelerin ticaretin ihtiyaçlarına esnek bir şekilde yanıt vermesi gerektiğini savunan bankacılık okulu ilkeleri modern bankacılık sisteminin zeminini oluşturmaktadır (Goodhart ve Jensen, 2015: 3-10). Dolayısıyla kısmi rezerv sisteminin bu ekole bağlı olarak gelişmiş olduğunu söylemek mümkündür.

Modern bankacılık sistemi çerçevesinde merkez bankasının para arzı tanımları incelendiğinde M0, M1, M2 ve son olarak M3 para arzından oluştuğu görülmektedir. M0 ve M1 dar tanımlı para arzı olarak ifade edilebilmekte iken M2 geniş tanımlı para arzı, son olarak M3 ise en geniş tanımlı para arzı olarak ifade edilmektedir. Tedavülde bulunan, merkez bankası tarafindan basılan banknotlar ve darphane tarafindan basılan madeni paralar nakit olarak isimlendirilmektedir. Bu sebeple piyasada bulunan ve nakit olarak isimlendirilen M0, tedavüldeki banknotlar ve madeni paralardan banka kasalarında bulunan nakitlerin çıkarılması ile elde edilmektedir. Dar tanımlı para arzı olarak adlandırılabilecek olan M1 para arzı ise M0'a vadesiz mevduatların eklenmesi ile oluşturulmaktadır. 
M0 = Merkez Bankası Tarafından Basılan ve Tedavülde Bulunan Banknotlar + Darphane Tarafından Basılan ve Tedavülde Bulunan Madeni Paralar - Banka Kasalarında Yer Alan Nakit

M1 = M0 + Vadesiz Mevduatlar (TL Cinsinden Vadesiz Mevduatlar + Yabancı Para Cinsinden Vadesiz Mevduatlar)

Dar tanımlı para arzı olarak ifade edilen M1'e iktisatçılar arasında daha az likit özelliğe sahip olması dolayısıyla para benzerleri olarak da isimlendirilen vadeli mevduatların eklenmesi ile geniş para arzı olarak ifade edilebilen M2 para arzı elde edilmektedir. M3 para arzı ise M2 para arzına repo, para piyasası fonları ve ihraç edilen menkul değerlerin eklenmesi ile elde edilmekte ve en geniş para arzı olarak tanımlanmaktadır.

M2= M1 + Vadeli Mevduat

M3= M2 + Repo + Para Piyasası Fonları + (Bankalar Tarafından) İhraç Edilen Menkul Değerler

Merkez bankası tarafından para arzının artırılmasının yanı sıra bankalar da vadesiz mevduat miktarına bağlı olarak para arzını etkileyebilmektedirler. Bankalar kendilerine yatırılan vadesiz mevduatın tamamını rezerv olarak muhafaza edebilecekken modern bankacılık gereği bir kısmını bankada tutup geri kalan kısmını ise faizle borç verme yöntemini de tercih edebilmektedirler. Bankaların uygulayabilecekleri ilk seçenek tam rezerv sistemine karşılık gelmekte iken ikinci seçenek ise bankaların uygulamayı tercih ettikleri kısmi rezerv sistemidir. Bu sisteme dayalı olarak bankalar kaydi para oluşturmakta ve böylece merkez bankasının yanı sıra para arzına etki etmektedirler. Bankalar tarafından oluşturulan kaydi para oluşum formülü ise aşağıdaki gibi ifade edilebilmektedir; bankaya yatırılan ilk mevduat * (1/karşıllk oranı)

Bu durumda bankaya yatırılan ilk mevduat tutarının 1000 \$ ve karşılık oranının da \%10 olduğu varsayımında bankaların;

1000 * $(1 / 0.10)=10000$ \$lık mevduat oluşturduğu anlaşılmaktadır.

Bankaların kaydi para miktarlarını artırmaları daha fazla kredi verebilecekleri anlamına gelmekte ve bu durum da ekonomi üzerinde son derece önemli bir etki oluşturmaktadır. Yeni para oluşturulmadığı takdirde borç alanların büyük bölümü borcunu ödeyemez hale gelmekte, bireyler ve işletmelerin iflasları söz konusu olmaktadır. $\mathrm{Bu}$ durum yeni para oluşturulmasını zorunlu hale getirmekte iken para arzının artırılması da ekonomide bir dizi problemin oluşmasına neden olmaktadır (Diwany, 2011: 65-67). Enflasyon, borçlanma, gelir dağılımı adaletsizliği bu problemlerin başında gelmektedir.

\subsection{Kısmi Rezerv Bankacılığı Sisteminin Ekonomi Üzerindeki Olumsuz Etkileri}

Kısmi rezerv bankacılığının uygulandığı ekonomilerde başta yüksek enflasyon oranları olmak üzere, iç ve dış borçlanmaların artması, gelir dağılımı eşitsizliklerinin artış göstermesi, reel ekonominin küçülmesi, enflasyonu dengelemek amacıyla kullanılan faiz oranları negatif yönde etkilenerek iç piyasada ekonominin genel dengesini bozucu bir etki meydana getirirken dış piyasalarda da rekabet edebilirlik seviyesini olumsuz yönde etkileyen bir dizi ekonomik sorunla karşı karşıya kalınmaktadır.

Fiyatlar genel düzeyinde sürekli artışlar olarak tanımlanan enflasyon ekonomik denge üzerinde son derece etkilidir. Özellikle piyasada para arzını artırmak enflasyonu tetikleyici bir unsur olarak değerlendirilmektedir. Ancak enflasyonun nedeni olarak merkez bankasının para basarak para arzını artırmasından ziyade ticari bankacılık sisteminin para arzını genişletmesi gösterilmektedir (Jaffar vd., 2017: 279). Kısmi rezerv bankacılı̆̆ının geçerli olduğu modern finansal sistemlerde sınırsız para arzı sürekli enflasyonist baskılar oluşturmakta bu durum da paranın değerini düşürmektedir (Shapiee and Zahid, 2014: 769). Bu sebeple merkez bankası tarafından gerçekleştirilen para arzından ziyade özellikle ticari bankalar tarafından oluşturulan kaydi para neticesinde enflasyon oranlarının artmış olduğu anlaşılmaktadır.

Ticari bankaların kredi oluşturarak para arzını artırmaları neticesinde karlılık oranları da artmaktadır. Söz konusu bankaların karlılık oranları para arzının genişlemesine katkıda bulunan krediye bağlı olduğu için kar maksimizasyonunu düşünen bankalar para arzını artırma anlamında bir sınırlandırmaya gitmemektedirler (Javaid, 
2017: 5). Böylece ekonomide enflasyonun sürekli artış gösterdiği ve paranın da değerinin düştüğü bir sonuç ortaya çıkmaktadır.

Enflasyonun ekonomi üzerinde gelir dağılımı eşitsizliğini artırıcı bir etkisi bulunmaktadır. Enflasyon zengin ile fakir arasındaki uçurumu daha da büyütmekte, temelde oluşan bu eşitsizlik mevcut mali piyasalarda bulunanlar için son derece karlı bir durum meydana getirmektedir. Zenginler enflasyonist dönemlerde değer kazanacak çok sayıda varlığa sahipken yoksulların ve orta sınıfın birikim değeri düşmekte ve hayat pahalılığı arttıkça da söz konusu yoksul kesim zor günler yaşamaya devam etmektedir. Ayrıca yüksek enflasyon oranlarının hakim olduğu ekonomilerde çoğu eğitimli ve çalışkan olan orta sınıfın daha fakir bir sınıf haline gelmesi kaçınılmaz bir durum olarak görülmektedir (Jaffar vd., 2017:280). Dolayısıyla para arzının artmasına bağlı olarak meydana gelen yüksek enflasyon oranlarının özellikle düşük gelirli kesimi çok daha fazla etkileyerek ülke genelinde yoksulluk oranlarının artmasına neden olduğu söylenebilir.

Enflasyon artışının önüne geçilebilmesi için merkez bankaları para politikası araçlarını kullanmaktadırlar. Enflasyon oranlarını düşürmeyi hedefleyen merkez bankası öncelikle politika faiz oranlarını artırarak para arzını azaltmayı amaçlamaktadır. Yaygın görüş olarak da faiz oranlarının artırılması ile birlikte para arzının azalacağı dolayısıyla da enflasyon oranlarının gerileyeceği fikri hakimdir.

Diwany’e göre, enflasyon oranlarını düşürmeye yönelik faiz oranlarının artırılması fikri en büyük ekonomik yanılgılardandır. Bu durumun en büyük gerekçesi olarak da faiz oranlarının artırılması ile alacak ve borç bakiyelerinin çok daha hızlı bir şekilde artışının teşvik edilmesini göstermektedir. Bu sebeple söz konusu durum uzun vadede değerlendirildiğinde para arzının azaltılamaması bir yana borç düzeyinin artması sorunu ile de karşı karşıya kalınmaktadır (Diwany, 2011:90). Netice itibariyle faiz oranlarının artırılmasının enflasyonu düşürme konusunda etkin bir araç olmadığını söylemek mümkündür.

Bankaların kaydi para oluşturmasına bağlı olarak para arzının artması servetin sosyal dağılımının da para basanın lehine olacak şekilde değişmesine neden olmaktadır. Servetin bu şekilde para basana doğru yer değiştirmesi neticesinde bankalar söz konusu serveti ya üretim yapmak için ya da tekrar kredi verme yoluyla değerlendirmektedirler. Ancak kaydi para üreten bankalar açısından daha avantajlı olması sebebiyle çoğunlukla tekrar kredi verme yöntemini tercih ettikleri bilinmektedir (Mises, 1953: 349).

Bankacılık sisteminin oluşturduğu her kredi daha fazla mevduat oluşturmakta ve sonuçta daha fazla kredi fonlanmaktadır. İnsanların finansal durumu kötüleştikçe de daha fazla borç almakta böylece kredilerin genel kullanılabilirliği de artmaktadır. Yani borçlanmaya devam edildikçe bankalar da daha fazla borç sunmaya istekli hale gelmektedirler (Dyson vd., 2010: 20). Borçluların her zaman söz konusu bankalardan aldıkları bu krediler karşılığında faiz ödemeleri gerekmektedir. Böylece ticari bankalar aslında var olmayan bir parayı ödünç vermekte ve ardından borçlunun faiz ödemesini de talep etmekte ve bunun için de borçludan bir teminat almaktadırlar. Faiz içeren bu borçlar zaman geçtikçe büyümektedir. Ancak bu kredileri geri ödeyecek para arzı ve faiz yalnızca ek krediler veren bankalar tarafından genişletilebilmektedir. Anapara tutarı kredinin yapıldığı anda oluşturulmakta iken sonraki dönemlerde ödenmesi gereken faiz için para henüz oluşturulmamaktadır. Dolayısıyla borçlular borçlarını ödemek adına mevcut kıt para için rekabet etmek durumunda kalmaktadırlar. Netice itibariyle herkesin kazanamadığı bu sistemde kredilerini temerrüde düşüren borçlular teminatlarını kaybetmektedirler (Greco, 2001: 21). Böylece zaten ekonomik anlamda yeterli kaynağa sahip olmadıkları için borçlanmak zorunda olanlar bu gelişmelerle beraber tekrar sorun yaşamaktadırlar. Dolayısıyla önemli düzeyde gelir ve servet dengesizlikleri ortaya çıkmaktadır.

Kısmi rezerv bankacılığında para arzının artmasına bağlı olarak borçlanma oranlarının artması neticesinde halkın gelirleri ve harcamaları azalmakta, para ise finans sektörüne yönlendirilmektedir. Finans sektörüne faiz olarak ödenen miktarlar finans sektörünü büyütürken reel ekonominin daralmasına neden olmaktadır (Dyson vd., 2010: 21-22). Ticari bankalar tarafından sistemde hiçbir şey üretilmeden ve karşılığında herhangi bir şey olmadan sadece kredi sözleşmeleri ile oluşturulan kaydi para gelir dağılımı adaletsizliğine neden olmaktadır. Yeni oluşturulan paraya erişen insanlar ekonomi üzerinde oldukça büyük etkiye sahip olan zenginlerdir. Dolayısıyla kısmi rezerv sistemine bağlı olarak oluşturulan kaydi para neticesinde servetin para oluşturmanın olağanüstü ayrıcalığına sahip 
olanların elinde birikmesi durumu ortaya çıkmaktadır. Böylece servet toplumda sadece birkaç kişinin elinde yoğunlaşmaktadır (Jaffar vd., 2017: 280).

Düşük faiz oranları, düşük enflasyon oranları, istikrarlı veya yüksek oranlı ekonomik büyüme gibi nispeten iyi huylu makroekonomik koşullar söz konusu olduğunda bile bu durum kişisel veya hanehalkı borcunun daha yüksek seviyelere çıkmasına neden olarak ekonomileri dış şoklara karşı savunmasız hale getirebilmektedir. 2007 yılında Amerika Birleşik Devletleri'nde meydan gelen ve ardından tüm dünya ülkelerini derinden etkileyen küresel finansal krizde de aynı durum söz konusu olmuştur. Başlangıçta bankaların geri ödenmesini bekledikleri kredilerin geri ödenmemesi ile birlikte banka gelirlerinde büyük bir sıkıntı yaşanmış ve netice itibariyle yaşanan gelişmeler bankaların iflasları ile sonuçlanmıştır (Dyson vd., 2010: 20). Bu durum gerçekte olmayan, hayali olarak üretilen kaydi paranın başlangıçta bir gelişmiş ülke ekonomisini ardından küreselleşmenin etkisiyle tüm dünya ülkelerini nasıl olumsuz yönde etkilediğinin bir göstergesidir.

Bir ekonomide enflasyonist olmayacak ve sosyal olarak istenen hedefleri gerçekleştirebilecek şekilde verimli üretimlerde kullanılacak olan işlem amaçlı para talebinin artırılabilmesi için ihtiyati ve spekülatif amaçlı para talebinin mümkün olduğu kadar azaltılması gerektiği belirtilmektedir. Çünkü bir para arzı karşılığında ihtiyat ve spekülatif amaçlarla para talebi ne kadar fazla ise işlem amaçlı para talebi o kadar az olmaktadır (Chapra, 1996: 8). Ancak gerçekte olmayan para arzına müsaade eden kısmi rezerv bankacılık sisteminin hakim olduğu bir ekonomide spekülatif amaçlı para talebine oldukça fazla yer verilmektedir. Bu durumda mevcut para arzının ekonomik hedeflere uygun ve verimli olacak şekilde değerlendirilmesi minimum düzeye gerilemektedir.

Kısmi rezerv bankacılığı sistemi merkez bankasında tutulması gereken rezerv miktarını en düşük seviyede tutarak kredi verme olanaklarını artırma eğilimindedir. Tamamen kendi çkarlarını düşünen söz konusu bankaların bu hareketi ekonomi ve toplum üzerinde son derece önemli etkiler oluşturmaktadır. Güven üzerine inşa edilmiş olan bu sistemde borçluların borçlarını ödeyememe durumunda finansal istikrar ciddi anlamda zarar görmektedir. Ayrıca para arzının artmasına bağlı olarak enflasyon oranlarının artması, alım gücünün azalması borçlanmanın artmasının yanı sıra gelirin yoksuldan zengine doğru kaymasına neden olarak sosyo-ekonomik açıdan da dengesizliklere yol açmaktadır.

\section{Tam Rezerv Sistemi ve İslam Ekonomisinde Para Arzı}

Modern bankacılık sistemi olarak da adlandırılan kısmi rezerv bankacılığı sisteminin ekonomi üzerinde neden olduğu istikrarsızlıklara ve bunların sonucunda toplumda ekonomik anlamda meydana gelen sorunlara çözüm yolları araştırılmıştır. Özellikle 1929 Büyük Buhran sonrasında iktisatçıların bir kısmı yaptıkları çalışmalar neticesinde sorunun kaynağının bankalar tarafından oluşturulan kaydi para olduğunu tespit etmişlerdir. Bunun neticesinde de hükümetin para arzını \%100 kontrol edebileceği bir sisteme geçiş sağlamak amacıyla Chicago Planı'nı geliştirmişlerdir. Chicago Planı'nın temel özelliği ise bankaların \%100 rezerv özelliğine sahip olmaları gerekliliğidir (Zaman, 2015:9). Modern bankacılık sistemi geliştirilmeden önce 17. Yüzyılın ortasına kadar geçerli olan tam rezerv bankacıllğı olarak da isimlendirilen \%100 rezerv sistemi asıl sistem iken alternatif sistem olarak değerlendirilmeye başlanmış olduğu görülmektedir.

Tam rezerv sistemi Irving Fisher (1935) tarafından da önerilen bir sistemdir. Fisher, 1935 yllında yayınladığı 100\% Money adlı eserinde 1929 yılında yaşanan ekonomik kriz neticesinde ABD ekonomisi için para arzı miktarlarını değerlendirmiş ve mevcut para miktarının büyük çoğunluğunun banka parası şeklinde oluşturulmuş olduğunu tespit etmiştir. Ayrıca ekonomide kaynakların ve iş gücünün fazla olmasına karşın ticari işlemlerini yürütecek yeterli para olmadığı için milyonlarca işçinin de atıl kaldığını beyan etmiştir (Diwany, 2011: 107-108). Fisher bu çalışmasında 1929 Büyük Buhran olarak nitelendirilen krizin ABD ekonomisi üzerindeki etkilerini incelerken kısmi rezerv sistemine bağlı bir ekonomik yapıda bankaların oluşturduğu kaydi paranın söz konusu ekonomi üzerindeki olumsuz etkilerini tespit etmiştir. Bu anlamda kısmi rezerv sisteminden ziyade para basma işleminin tamamen devlet tarafından gerçekleştirildiği ve kontrolünün de yine devlete ait olduğu tam rezerv sistemini önermiştir. 1929 Büyük Buhranın etkileri uzun süre devam edince 1930’lu yıllar itibariyle tam rezerv bankacılığı sistemine yönelik araştırmaların ve tekrar uygulama açısından talebin arttı̆̆ 1 ifade edilebilir.

Mises (1953), bir bankanın müşterilerinin kullanabileceğinden daha fazla para ihraç etmesinin mümkün olmadığını, fazla miktarda kaydi para üretmenin sonunun ise bir felaket olduğunu ifade etmiştir. Merkez bankası 
ile kaydi para oluşturan bankaları kredi veren bankalar olarak sınıflandırmaktadır. Bu bankalardan ilki olan merkez bankasının tekele sahip, ayrıcalıklı bir banka olduğunu, ikinci grup bankalar olarak belirtilen bankaların da merkez bankaları ile rekabet edebilecek güçlerinin olmadığını, her zaman üretmiş oldukları kaydi para karşılığında belirli bir miktarı ellerinde bulundurmak zorunda olduklarını belirtmiştir. Kaydi para üretmenin ekonomi üzerindeki olumsuz etkileri neticesinde paranın gücünü koruyabilmek, enflasyonu düşürebilmek gibi amaçlarla altın standardına dönüşü teşvik etmiş ve sistemin işlerlik kazanabilmesi için bankaların tam rezerv sistemi ile çalışmaları gerekliliğini ifade etmiştir. Kaydi para üretmenin ekonomide oluşturduğu sorunların tespiti ve çözüm yolu olarak da tam rezerv sisteminin ve alıı standardının teşvik edilmesi arz edilen paranın bir karşılığının olması gerektiği görüşünün ağır bastığını göstermektedir.

Rothbard (2001) ise, kısmi rezerv sistemine bağlı olarak kaydi para üretmenin mevcut mal miktarından daha fazla oranda ödeme taahhüdü verildiği anlamına geldiğini ve bu durumun da yasallaştırılmış sahtecilik olduğunu ifade etmiştir. Kısmi rezerv bankacıllğının hem ahlaki hem de piyasa ekonomisinin temelleri için bir felaket olduğunu belirtmiştir. Dolayısıyla para arzı konusunda \%100 rezerv sisteminin ekonomik açıdan serbest piyasa ve mülkiyet hakları üzerinde son derece etkili olduğu görüşünü bildirmiştir.

Kısmi rezerv sisteminde bankaya yatırılan mevduatın bir kısmı merkez bankasında tutulmak zorunda iken büyük bir kısmı ise faiz karşlığında kredi olarak bankanın kullanımına açık hale gelmektedir. İslami açıdan değerlendirildiğinde bankalar tarafından oluşturulan kaydi para ile ilgili en büyük sorun kısmi zorunlu karşılık ihtiyacına ilişkin düzenleme ve bankanın oluşturduğu kredidir. Kısmi rezerv sisteminde bankalar tarafından ödünç verilen para yeni mevduat olarak bankacılık sistemine geri dönecek ve bu paranın büyük bir kısmı tekrar ödünç verilebilecektir. $\mathrm{Bu}$ aşamada krediden bir kredi daha oluşturulmakta ve bu döngü devam etmektedir (Shapiee and Zahid, 2014:196). Tam rezerv sisteminde ise yatırılan vadesiz mevduat her an çekilmek üzere bankada tutulmakta, vadeli mevduat ise banka tarafından mevduat sahibinden alınan borç olarak nitelendirmekte ve kredi olarak başka müşterilere verilebilmektedir. Ancak kısmi rezerv sisteminden farklı olarak tam rezerv sisteminde kredi olarak verilen miktar piyasada para olarak işlev görmediği için para arzını artıııı bir etki oluşturmamaktadır. Kısmi rezerv bankacılığı sisteminde bankaların faiz karşılığında verdikleri kredilerin piyasada nakit veya çek olarak işlev görmesi sebebiyle kaydi para oluşmaktadır. Oluşan kaydi paranın ekonomi üzerinde neden olduğu negatif etkilerin yanı sıra faiz ile işlem görüyor olması bu sistemin İslam ekonomisi ilkeleri ile bağdaşmamasına neden olmakta ve İslami açıdan büyük bir sorun teşkil etmektedir.

İslam ekonomisinde para ve mal farklı iki kavram olarak değerlendirilmektedir. Bu iki kavram arasındaki en önemli ayırt edici özellik ise malın bir doyma noktası olmasına rağmen paranın doyma noktasının olmamasıdır (Eskicioğlu, 2009). Bu noktada İslam ekonomisine göre para bir mal değil, mala ulaşma aracıdır. Dolayısıyla para ihtiyat ve spekülatif amaçlı değil, bir mal ve hizmeti temin edebilmek amacıyla sadece mübadele amaçlı olarak talep edilmelidir. Paranın bu özelliği ise her malın bir bedeli olduğu, paranın da bir mal olması sebebiyle bedelinin faiz olduğu gerekçesi ile faizi savunanların bu görüşünü bertaraf etmektedir.

İslam ekonomisine göre faiz, pek çok önemli sorunun temel kaynağını oluşturmaktadır. Toplum içerisinde sermayenin özgürce dolaşmasının önündeki en büyük engellerden biri faizdir. Ayrıca sermayenin yoksullardan zenginlere doğru akmasına neden olarak gelir dağılımındaki adaletsizliği daha da artırıcı bir etki oluşturmaktadır. Faizli alışverişlerde taraflardan sadece biri fayda sağlamakta iken diğeri zarar etmektedir. Bu ekonomik zararlarının yanı sıra faizli sistem cimrilik, bencillik, duyarsızlık gibi duyguların toplumda artış göstermesine neden olmaktadır. Ayrıca insanların arasındaki merhamet ve dayanışmayı azaltarak sosyal açıdan da birtakım olumsuz etkiler meydana getirmektedir (Mevdudi, 2016: 256-257).

İslam ekonomisinde faiz, emeksiz kazanç elde edilmesine firsat sunması sebebiyle bir sömürü aracı olarak değerlendirilmektedir. Kaydi para oluşumunun faiz getirisi üzerine temellendirilmesi neticesinde reel ekonomiden ziyade finans ekonomisinin hakimiyet alanının genişlemesi ve buna bağlı olarak da ekonominin dış şoklara karşı savunmasız bir hale gelmesi gibi nedenlerle İslam ekonomisi faizi tamamen yasaklamaktadır. Para talebinin de sadece işlem amaçlı olması gerektiğini belirten İslam ekonomisi kuralları gereği özünde faiz kazancı elde etme amacını barındıran spekülatif amaçlı para talebi tasvip edilmediği için gerçekte olmayan, spekülatif amaçlı kullanılan, üzerinden ciddi miktarlarda faiz geliri elde edilen kaydi para konusunda da İslam ekonomisi düşünürlerinin büyük çoğunluğunun olumsuz görüşe sahip olduğu belirtilmektedir (Sugözü, 2017: 193-203). 
Tüm bu sebeplerle İslam ekonomisinde faize yer verilmemekte, bu sebeple para arzı konusunda da kısmi rezerv sisteminin aksine tam rezerv sisteminin önemini vurgulayan bir yapı mevcut olmaktadır.

İslami bankacilık sisteminde vadesiz hesap, istenilen her an çekilmeye hazır mevduat fonları olarak vedia esasına göre çalışmaktadır. Bu durumda bu hesaplarda \%100 rezerv oranı uygulaması gerçekleştirilmektedir. Ancak söz konusu hesaplardan bankacının işletme maliyetlerini karşılamak adına hizmet ücreti alınması mümkündür. Ödeme sistemini etkin ve verimli bir şekilde çalıştırabilmek için normal çekiş ve transfer olanakları sağlanarak bankaların rekabet edebilirlikleri de artırılmış olacaktır. Vedia esası dikkate alındığında vadesiz mevduat hesabındaki paraların bankalar tarafından faizsiz kredi olarak verilmesi mümkündür. Bunun için temelde iki koşul gereklidir. İlk olarak mevduatların sadece likidite uygun olduğunda çekilmesi şartı iken ikinci koşul ise fonların kredi olarak verilmesi sonucu meydana gelecek olan her türlü riskin mevduat sahibine aktarılması koşuludur (Diwany, 2011: 251). Kısmi rezerv sisteminde kaydi para oluşumuna bağlı olarak yüksek faiz getirisi olduğu için mevduat sahibinin mevduatına yönelik sunulan hizmetlerin karşılığındaki ücretler son derece düşük seviyede belirlenmekte hatta eğer mevduat yüksek düzeylerde ise herhangi bir ücret talebi dahi söz konusu olmamaktadır. Ancak tam rezerv sisteminde ise yüksek düzeyde faiz getirisi olmadığı için hizmet bedelleri biraz daha yüksek düzeylerde olabilmektedir.

Faizin geçerli olduğu geleneksel sistemde borç oranları bileşik faizle sonsuza kadar artmakta ve böylece servet transferi gerçekleşmekte iken, faizin olmadığı İslam ekonomisi kurallarının hakim olduğu bir ekonomide ise servet transferinden ziyade servet oluşumu söz konusu olmaktadır. Bu sistemde girişimcinin karı önceden belirlenmiş faiz oranına göre değil sermayedarla müşterek paylaşıma dayanmaktadır. Ayrıca faizin olmadığı bir sistemde bankalar için para oluşturmak karlı bir iş olmaktan çıkacağı için piyasada gereğinden fazla para arzı söz konu olmayacaktır. Kar ve zarar ortaklığı yatırımlarının amacı da toplam para pastasını büyütmek değil pastanın yeniden dağılımıdır (Diwany, 2011: 259-275). Para arzının gereğinden fazla olması durumunda meydana gelen ekonomik problemler faizin geçerli olmadığı sistemle beraber kendiliğinden ortadan kalkacaktır.

Bankaların üretmiş olduğu kaydi paralar bir sübvansiyon olarak değerlendirildiğinde bu sübvansiyonlardan bankacılık kamuoyunun, düşük faiz oranı ile bankalardan borçlanan ayrıcalıklı grup ve artan kar sebebiyle banka hissedarlarının yararlandığı ancak toplumun yoksul kesimi, muhtaç insanları ve bankacilık sektörü dışındakilerin bundan herhangi bir fayda elde edemediği ifade edilmektedir. Tam da bu noktada İslam'ın sosyal refah odaklı değer sisteminde para oluşturma gücünün sosyal bir ayrıcalık olarak görülmesi ve bu nedenle para oluşturulmasından elde edilen net gelirin genel refah için ve özellikle de pek çok yoksulun ekonomik seviyesinin iyileştirilmesi için kullanılması gerekmektedir (Chapra, 1985:92).

Bugün ekonomilerde devlet parasından ziyade banka parasının çok daha fazla olduğu bilinmektedir. Bu durum da ekonomik anlamda önemli bir risk unsuru oluşturmaktadır. İslami bankacılık modelinde mevduat sahiplerine vadesiz hesaplarından istediği zaman hesabının tamamının ödemesi gerçekleştirilebilmektedir. (Diwany, 2011: 254). Ancak kısmi rezerv sisteminde bunun mümkün olmaması ve de herhangi bir ekonomik problemde mevduat sahiplerinin pek çoğunun yatırımlarını istemeleri sebebiyle meydana gelen ekonomik riskin İslam ekonomisi anlayışındaki bankacılık modelinde geçerli olmadığı ortaya çıkmaktadır.

İslam ekonomisi gelir dağılımı adaletini benimseyen, varlığın adil paylaşımından yana olan, yoksulların ihtiyaçlarını göz ardı etmeyen, insanların içinde yaşadıkları topluma karşı sorumlu oldukları fikrini benimseyen bir yapıya sahiptir. Dolayısıyla da enflasyon oranlarındaki artış, borçlanma, haksız kazanç, gelir dağılımı eşitsizliği ve akabinde meydana gelebilecek yoksulluk gibi unsurlara neden olan faiz, İslam ekonomisi tarafindan kabul görmemektedir. Netice itibariyle kısmi rezerv sistemine bağlı olarak bankalar tarafından oluşturulan ve faiz getirisi üzerine temellendirilen kaydi para da İslam ekonomisi ilkeleri gereği kabul görmemekte bunun yerine yatırılan vadesiz mevduatın bankada tutulmasını öngören tam rezerv sistemi teşvik edilmektedir. 


\subsection{Bir İslam Ekonomisi Disiplini: Adil Ekonomik Düzen}

Temelini İslam ekonomisinden alan, Prof. Dr. Necmettin Erbakan tarafından Türkiye ekonomisi özelinde ileri sürülen, özünde fırsat eşitliği sunan, adaleti benimseyen, sömürüye müsaade etmeyen, ekonomik büyüme ve kalkınmanın önündeki engelleri ortadan kaldırmayı hedefleyen, ekonomik faaliyetleri teşvik eden ve bu anlamda da finans sektöründen ziyade reel sektörü önceleyen Adil Ekonomik Düzen İslam ekonomisinin bir disiplini olarak değerlendirilebilmektedir.

Adil Ekonomik Düzen, devletin ekonomideki rolü, vergi, para, kredi ve sigorta gibi iktisadi sistemlerin temel konuları üzerinde var olan ve geçerliliğini koruyan sistemlere göre farklı çözümler getiren yeni bir iktisadi sistem olarak tanımlanmaktadır. İslam ekonomisi kurallarını temel edinmesine rağmen doğrudan İslam'a, doğrudan İslam kurallarına atıfta bulunmamaktadır (Sugözü, 2017: 194).

Dünya genelinde yaşanan sorunların giderilememesi, çözüme kavuşturulamayan sorunların derinleşmesi ve imtiyazlı grupların oluşmasına bağlı olarak yeni sistem arayışlarının söz konusu olduğu bir ortamda Adil Düzen çalışmaları başlamıştır. Bu çalışmaların başlangıcı İzmir Akevler Kooperatifinde gerçekleşmiş akabinde Prof. Dr. Necmettin Erbakan'ın liderliğinde sistematiğe kavuşmuştur (Öztürk, 2017: 154). Necmettin Erbakan 1980'li yıllarda İslam esasına dayalı akademik ve uygulamalı çalışmalara girişmiş ve Adil Ekonomik Düzen adı alında bir program ortaya çıkarmıştır. Adil sistem, ekonominin yanı sıra siyasi, idari ve sosyal yapı hakkında da fikirler içeren bir sistemdir. Bu sistemin ekonomik ilkeleri Adil Ekonomik Düzen adıyla düzenlenmiştir (Sarıbaş ve Yumuşak, 2020: 318).

Erbakan, Adil Ekonomik Düzeni, ekonominin hiçbir aşamasında sömürüye izin vermeyen, firsat eşitliği sunan, herkese hakkını veren, eşit davranan, faydalı ve yapıcı faaliyetlere destek veren, ekonomik gelişmenin önündeki engelleri ortadan kaldıran bir ekonomik düzen olarak tanımlamıştır (Erbakan, 2019: 74). Bu tanımdan da anlaşılacağı üzere İslam ekonomisinde olduğu gibi Adil Ekonomik Düzende de sosyal refaha, gelir dağılımı adaletine son derece önem verildiği görülmektedir.

Erbakan'a göre Adil Ekonomik Düzenle birlikte faiz olmayacak, sağlam para sistemine geçilecek ve böylece paranın değeri hak ölçüsü olarak belirlenecek, karşılıksız para basımı gerçekleşmeyecek, paranın değeri düşürülemeyecek, haksız vergiler kaldırılacak, krediler ise adil ölçüler dikkate alınarak ekonomiye faydalı iş yapacak olan herkese verilecektir. Bu kuralların hayata geçirilmesi ile her şeyin fiyatı üçte birine düşecek ve herkesin alım gücü üç katına çıkacak, işletmeler aynı sermayeyle üç kat fazla üretim yapabilecek, istihdam üç kat artacak böylece Türkiye dünya genelinde en ucuz üretim yapan ülke haline gelecek bu durum da ihracatın artmasına neden olacak, Müslüman ülkeler arasında bir Ortak Pazar kurulacak ve yaşanan bu gelişmeler neticesine Türkiye dünya genelinde ekonomik anlamda en büyük ülkelerden biri haline gelecektir (Erbakan, 1991: 13). Erbakan 1980 ve 1990'lı yıllarda geçerli olan rant ekonomileri yerine Adil Ekonomik Düzenle birlikte kar ortaklığı sistemi ile faizsiz bir üretim üzerine yeni bir sistem inşa etmiştir (Ersin ve Yıldırım, 2015).

Erbakan, kapitalizm ve komünizmdeki faydalı yanların sisteme dahil edildiğini ancak zararlı yanların ise sistemde yer almadığını böylece Adil Ekonomik Düzenin tam ve mütekamil bir düzen olduğunu ifade etmiştir. Kapitalizmi, sömürü ve zulüm aracı olan faize yer vermesi sebebi ile tröst ve tekellerin oluşmasına mani olamadığı için eleştirirken komünizmi ise mülkiyet hakkına ve kara karşı çıkmaları sebebiyle insan tabiatına aykırı tutum sergiledikleri için eleştirmiştir. Adil Ekonomik Düzenin ise faize yer vermediğini, kara müsaade ettiğini, serbest piyasa rekabetini ve mülkiyet hakkını desteklediğini böylece tekelleşmeye ve tröstlere karşı çımakta olduğunu belirtmiştir (Erbakan, 1991: 18).

Adil Ekonomik Düzen, bugün dünya genelinde kabul gören ve geçerli olan kapitalist sistemin aksine toplum menfaatini gözetmeyen bireysel çıkarların eksik olduğunu ancak toplumun menfaatini bireyin menfaatine tercih etmenin de yanlış olduğu fikrini savunmaktadır. Bireyin öncelikli toplumun ise önemli olması sebebiyle bu iki kesim arasında bir tercih yapmanın son derece yanlış olduğunu ileri sürmektedir. Ayrıca sistemde kar-zarar ortaklığının önemi üzerinde durulmuştur (Öztürk, 2017: 160). Tarafların oluşacak kar veya zarara ortak olmaları anlamına gelen bu sistemde ortaklar çabaları nispetinde pay alacaklardır. Bu da sistemin adaleti temel aldığının bir göstergesidir. 
Adil Ekonomik Düzende, üretim, üretimi gerçekleştiren girişimci ile yönetici, iş̧̧i, hammadde, tesis, genel hizmet sunumunu gerçekleştiren devletin ortaklığı ile yapılmakta ve üretimden sonraki paylaşım da bu ortaklar arasında adil bir şekilde gerçekleştirilmektedir. Bu sistem hakkı üstün tutmakta ve toplumda bir ayrımcılık yapmamaktadır. Açık, sade, uygulaması son derece kolay ayrıca toplumda çatışmayı değil barışı teşvik edici bir sistemdir. Herkesi üretime teşvik etmekte, böylece ekonominin önündeki tüm engelleri kaldırarak kalkınmanın ve refah seviyesinin artmasına neden olmaktadır. Kapitalist sistemin haksız kredi dağıtımı ve yoksul halka yüksek faizli kredilerin ödetilmesi sonucunu meydana getiren bankacılık yapısına bağlı ortaya çıkan olumsuzluklar Adil Ekonomik Düzen ile birlikte çözüme kavuşacak, ekonomi hızlı bir gelişme sağlayacak dolayısıyla gelir dağılımı adaletsizlikleri son bulacaktır (Erbakan, 1991: 78).

Erbakan'ın Refahyol Hükümeti ile birlikte uygulama firsatı bulduğu Adil Ekonomik Düzen ilkeleri neticesinde konsolide bir kamu hesabı kurmuş, ardından faiz oranları düşmüş ve kamu kesimi bütçesi üzerindeki faiz yükü hafifletilmiştir. Ayrıca hükümet sosyal transferleri artırarak gelir dağılımını da iyileştirmeyi amaçlamıştır. Ancak Refahyol Hükümeti'nin 28 Şubat 1997 tarihinde darbeyle istifaya zorlanması ve 2011 yılında da Necmettin Erbakan'ın vefatı ile Adil Ekonomik Düzenin Türk siyasetindeki popülaritesi giderek azalmıştır (Sarıbaş ve Yumuşak, 2020: 319). Uygulandığı kısa dönemde Türkiye ekonomisi üzerinde belirtildiği üzere önemli etkiler oluşturmuştur. Bugün geçerli olan kısmı rezerv sistemi ve buna bağlı olarak üretilen kaydi paranın ekonomiler üzerinde ne kadar olumsuz etkiler oluşturduğu göz önüne alınırsa Adil Ekonomik Düzenin para tanımı ve para arzı konusunda ileri sürdüğü para=mal ilkesi bu anlamda son derece önemlidir.

\subsection{Adil Ekonomik Düzende Para=Mal İlkesi}

Adil Ekonomik Düzende para, bir kimseye yapmış olduğu herhangi bir üretim karşıllı̆ında ve üretimine eş değer olacak tüketme hakkı olduğunu belirtmek amaciyla sunulan özel senetler olarak tanımlanmaktadır (Erbakan, 2019: 81). Buradan anlaşılacağı üzere ekonomide yapılan üretimler karşılığında para arzının olması gerektiği, paranın muhakkak bir mal karşılı̆̆ının bulunması gerektiği belirtilmektedir. Adil Ekonomik Düzen ilkeleri incelendiğinde para arzının tamamen devlete ait olması gerektiği, basılan paranın da bir emtia karşılığının bulunması gerektiği görülmektedir. Bu anlamda Adil Ekonomik Düzen ve İslam ekonomisinin para arzı konusunda son derece hassas olup spekülatif kazançların etkin olduğu finans sektörünün hakim sektör olmasından ziyade reel sektörün hakimiyetini önemsediği ifade edilebilir.

Adil Ekonomik Düzendeki para anlayışı İslam ekonomisindeki anlayışla benzerlik göstermektedir. Parayı mal olarak görmeyen ve sadece mübadele amaçlı talep edildiği yönündeki fikri savunan İslam ekonomisi ilkelerinin Adil Ekonomik Düzende de geçerli olduğu görülmektedir. Ayrıca İslam'da asla kabul edilmeyen faiz, Adil Ekonomik Düzende de kabul görmemekte, oluşturulan sistemde faize kesinlikle yer verilmemektedir.

Adil Ekonomik Düzenin temel şartı ne kadar tüketeceksen o kadar da kendin üretmelisin ve başkasının hakkını yememelisin ilkesidir. Bu ilke ekonominin tamamı için geçerlidir. Bir kimsenin üretmiş olduğu bir mala ilişkin o malın değerince kendisine istediği maldan tüketebilmesi için bir özel senet verilmektedir. Bu senetler para olarak adlandırılmaktadır. Bu durumda Adil Ekonomik Düzende para; herhangi bir üretim gerçekleştiren kişiye üretimine eşdeğer oranda tüketme hakkı olduğunu belirtmek üzere verilen özel senetler olarak tanımlanmaktadır (Erbakan, 1991: 25-26).

Adil Ekonomik Düzen para ile ilgili bir takım temel şartlar ve aksiyomlar barındırmaktadır (Erbakan, 2019: 81-83):

- Para=Mal İlkesi: Bu ilkeye göre bir toplum ne kadar üretim yapmış ise onun karşıllığı kadar tüketim hakkına sahiptir. Dolayısıyla üretilen malların toplam değerine karşılık gelecek miktarda para arz edilmesi gerekmektedir.

- Faiz Yok İlkesi: Faiz, üretmeyenlerin üretenlerden belirlenen faiz oranı kadar malı zorla almaları anlamına geldiği için haksızlık ve zulüm olarak değerlendirilmektedir. Bu sebeple bu sistemde faiz yer almamaktadır.

- Karşılıksız Para Yok İlkesi: Para üretim yapmanın karşılığında arz edilmektedir. Bu durumda bankalar tarafından üretilen ve gerçekte olamayan kaydi paranın bu sistemde yeri yoktur.

- Paranın Eşya ile Tanımlanması İlkesi: Piyasada bulunan paranın arsa, standart mal, tesis, altın-döviz karşılığı olmasını ifade etmektedir. 
Adil Ekonomik Düzen "Para=Mal” ilkesi ile kısmi rezerv sistemine bağlı olarak bankaların gerçekleştirdiği ve anaparanın neredeyse on katına karşlık gelen, hayali para olarak da nitelendirilebilen kaydi para olgusunun tam aksi yönde bir para arzı kavramını benimsemektedir. Para arzının karşılıksız olarak değil üretime bağlı olarak gerçekleşmesi neticesinde fiyat artışlarının önüne geçerek haksız kazançların önleneceği ve adil bir ekonomik yapının zemininin hazırlanacağı anlaşılmaktadır. Para arzının üretime bağlı olarak gerçekleşmesi gerektiğinin belirtildiği bu sistemde kaydi paranın neden olduğu, ekonomide kronikleşen ve yapısal sorunlar olarak değerlendirilen pek çok sorundan kurtulmanın yanı sıra üretimin teşvik edilmesi sebebiyle ekonomik büyüme rakamları ve refah seviyesinin artması beklenmektedir.

Erbakan (2019), dünya genelinde yaşanan küresel ekonomik krizlerin pek çoğunda olduğu gibi 2008 Küresel Finansal Krizin de en önemli nedeninin karşılıksız para basma ve buna bağlı olarak finans sektörünün sanal bir şekilde şişirilmesi olduğunu, piyasada mevcut olan mal ve hizmetin 10 katı kadar para ve para işlevi gören değerlerin yer aldığını, Türkiye'de ise bu oranın ilgili dönemde yaklaşık 8 kat civarında olduğunu belirtmiştir. Bugün Türkiye'de basılan para miktarı ve verilen kredi miktarlarına ise Tablo1 ve Tablo 2'de yer verilmektedir.

Tablo 1. Türkiye Ekonomisinde Yıllar İtibariyle Emisyon Miktarı ile Kredi Miktarı (Milyon TL)

\begin{tabular}{|l|c|c|c|c|}
\hline Yıllar & Emisyon Miktarı & $\begin{array}{c}\text { Kredi Miktarı (TL } \\
\text { Cinsinden Verilen) }\end{array}$ & $\begin{array}{c}\text { Kredi Miktarı (Yabancı } \\
\text { Para Cinsinden Verilen) }\end{array}$ & Toplam Kredi Miktarı \\
\hline 2019 & 143151 & 1528376 & 998700 & 2527076 \\
\hline 2020 & 202852 & 2084839 & 1176327 & 3261166 \\
\hline $2021^{*}$ & 186108 & 2390527 & 1291018 & 3681545 \\
\hline
\end{tabular}

Kaynak: TCMB ve BDDK, Not: Yıllık veriler aylık verilerin ortalaması alınarak elde edilmiştir.

*2021 yılı verileri ilk dört aya aittir.

2019, 2020 yılı ile 2021 yılının ilk dört ayına ait Türkiye Cumhuriyeti Merkez Bankası tarafından yayınlanan emisyon miktarı ile Bankacılık Düzenleme ve Denetleme Kurumu tarafından yayınlanan kredi miktarı verileri Tablo 1'de yer almaktadır. Merkez Bankası tarafından basılan ve fiziki olarak piyasada yer alan para miktarını ifade eden emisyon miktarı 2019 yılında 143 milyar TL iken aynı yıl bankalar tarafından Türk Lirası cinsinden verilen kredi miktarı ise 1 trilyon 528 milyar TL'dir. Ayrıca aynı yıl yabancı para cinsinden verilen kredi miktarı 998 milyar 700 milyon TL değerinde olmuş dolayısıyla toplamda 2 trilyon 527 milyar TL değerinde kredi verilmiştir. 2019 yılında bankalar tarafından Türk Lirası cinsinden verilen kredi miktarının Merkez Bankası tarafından oluşturulan paradan yaklaşık 11 kat, toplam kredi miktarının ise 17,6 kat daha fazla olduğu görülmektedir. 2020 yılı verileri incelendiğinde ise yıllık ortalama 202 milyar 852 milyon TL emisyon söz konusu iken Türk Lirası cinsinden 2 trilyon 85 milyar TL, yabancı para cinsinden verilen kredi ile birlikte ise toplam 3 trilyon 261 milyar TL değerinde kredi verilmiştir. Söz konusu yıl ise piyasada mevcut olan mal ve hizmetin Türk Lirası cinsinden verilen kredi miktarı ile değerlendirildiğinde 10 katı kadar, toplam verilen kredi miktarı ile karşılaştırıldığında da 16 kat daha fazla para veya para işlevi gören değer oluşturulmuştur. Aynı durum 2021 yılı için de artarak devam etmektedir. 2021 yılında bu oran Türk Lirası cinsinden verilen kredi miktarı ile değerlendirildiğinde yaklaşık 13 kat civarındadır. Toplam kredi miktarı ile değerlendirildiğinde ise kredi miktarının emisyon miktarından 19,8 kat daha fazla olduğu görülmektedir.

Tablo 2'de, 2021 yılı emisyon miktarı ile kredi miktarına ait verilerin daha ayrıntılı bir şekilde incelenebilmesi için bu yıla ait ilk 4 aylık veriler yer almaktadır.

Tablo 2. Türkiye Ekonomisinde 2021 Yılı Gerçekleşen Emisyon Miktarı ve Kredi Miktarı

\begin{tabular}{|l|c|c|c|c|}
\hline \multicolumn{1}{|c|}{ Aylar } & $\begin{array}{c}\text { Emisyon Miktarı } \\
\text { (Milyon TL) }\end{array}$ & $\begin{array}{c}\text { Kredi Miktarı (TL } \\
\text { Cinsinden) (Milyon TL) }\end{array}$ & $\begin{array}{c}\text { Kredi Miktarı (Yabancı } \\
\text { Para Cinsinden) (Milyon } \\
\text { TL) }\end{array}$ & $\begin{array}{c}\text { Toplam Kredi } \\
\text { Miktarı (Milyon TL) }\end{array}$ \\
\hline Ocak & 182464 & 2346998 & 1205854 & 3552852 \\
\hline Şubat & 180038 & 2372639 & 1224582 & 3597221 \\
\hline Mart & 185027 & 2417946 & 1357339 & 3775285 \\
\hline Nisan & 196902 & 2424525 & 1376294 & 3800819 \\
\hline
\end{tabular}

Kaynak: TCMB ve BDDK 
2021 yılı ocak ayında toplam emisyon miktarı 183 milyar TL iken toplam Türk Lirası cinsinden verilen kredi miktarı ise 2 trilyon 347 milyar TL ile para arzının yaklaşık 13 kat fazlası olarak gerçekleşmiştir. Aynı ayda 1 trilyon 206 milyar TL değerinde yabancı para cinsinden kredi verilmiş ve toplamda 3 trilyon 553 milyar değerinde kredi verilmiştir. Toplam kredi miktarı değerlendirildiğinde ise emisyon miktarından 19,5 kat fazla olduğu görülmektedir. Şubat ayında emisyon miktarı ocak ayına göre bir miktar gerileyerek 180 milyar TL olarak gerçekleşmişken Türk Lirası cinsinden kredi miktarının gerilemediği gibi bir önceki aya göre artarak 2 trilyon 373 milyar TL olarak gerçekleştiği görülmektedir. Yabancı para cinsinden verilen kredi miktarı ile birlikte toplamda 3 trilyon 597 milyar TL değerinde kredi verilmiş, sadece Türk Lirası cinsinden verilen kredi ile 13,2 kat, toplam kredi miktarı ile incelendiğinde ise neredeyse 20 kat fark oluşmuştur. Emisyon miktarı ile toplam kredi miktarı arasındaki en fazla fark ise 20,4 kat farkla mart ayında gerçekleşmiştir. Bu ayda toplam kredi miktarı 3 trilyon 775 milyar TL iken emisyon miktarı ise 185 milyar TL seviyesinde gerçekleşmiştir. Nisan ayında ise 197 milyar TL emisyon gerçekleştirilirken Türk Lirası cinsinden verilen kredi miktarı 2 trilyon 425 milyar TL, toplam kredi miktarı ise 3 trilyon 801 milyar TL değerinde gerçekleşmiştir. Dolayısıyla Türk Lirası cinsinden kredi miktarı emisyon miktarından 12,3 kat, toplam kredi miktarı ise 19,3 kat daha fazladır.

2021 yılı ilk çeyreğinde bankalar tarafından verilen kredi miktarının Merkez Bankası tarafından gerçekleştirilen emisyon miktarı ile karşılaştırıldığında Türk Lirası cinsinden ortalama 13 kat, yabancı para ile verilen kredi miktarının da eklenmesi ile birlikte toplam kredi miktarından ise ortalama 19 kat daha fazla olduğu görülmektedir. Bu durum piyasada gerçekleştirilen mal ve hizmet üretiminin kat be kat daha fazlası kadar paranın piyasaya girmiş olduğu anlamına gelmektedir. Daha açık bir ifade ile reel sektörden ziyade finans sektörüne yönelik bir sanal büyüme gerçekleşmektedir. Adil Ekonomik Düzende geçerli olan para=mal ilkesi gereği üretim neticesinde para arzı gerçekleşeceğinden finans sektörünün sanal büyümesinden ziyade reel ekonominin büyümesi söz konusu olacaktır. Bu durum da makroekonomik açıdan temelleri sağlam bir ekonomik yapının oluşmasını sağlayacaktır.

Adil Ekonomik Düzende para konusu ile ilgili önemli hususlardan bir diğeri de faiz kavramıdır. Faiz İslam'da haksız kazanç ve sömürü aracı olarak nitelendirilmekte bu sebeple de kesinlikle kabul görmemektedir. İslam ekonomisi modeli olarak değerlendirilen Adil Ekonomik Düzende geçerli olan üretim karşıllı̆ı tüketme hakkına istinaden arz edilen paraya karşlık Kapitalist sistemde ise faiz anlayışıyla beraber üretim yapmadan tüketme hakkı tanınmaktadır. Bu da haksız kazanca, zulme sebep olmaktadır. Bu durumun neticesinde sermayeyi ele geçiren kesim faiz yoluyla emek harcamadan, haksız yere büyük kazançlar elde etmekte iken faizin neden olduğu bu durum yoksul insanları ise zaruri sebepler dolayısıyla gayri ahlaki yollara itebilmektedir. Netice itibariyle toplumlarda ahlaki çöküş hasıl olmaktadır. Tüm bu sebeplerden ötürü Adil Ekonomik Düzende faiz kabul edilmemektedir.

Adil Ekonomik Düzenin para ile ilgili 4 temel şartının yanı sıra paranın 3 temel ilkesi daha mevcuttur. Söz konusu ilkeler gereği para istenildiği anda değiştirilebilme özelliğine sahip olmalıdır. Yani herkes istediği zaman malını temsil eden ve elinde mevcut bulunan senedi paraya çevirebilme hakkına sahip olmalıdır (Erbakan, 2019: 83). Kısmi rezerv sisteminde vadesiz mevduat sahiplerinin istedikleri zaman parasının tamamını çekme özgürlüğüne sahip olmamaları bu anlamda önemli bir dezavantaj olarak değerlendirilmektedir.

Herkese eşit muamele ilkesi gereği ülkenin her yerinde, herkese aynı fiyat uygulaması yapılmalıdır. Dolayısıyla ülkenin tamamında eşit muamele koşulları geçerli olmaktadır. Son olarak fiyatların arz ve talebe dayalı kıstaslara göre tespit edildiği bu sistemde fiyatlar daha adil ve uygun kriterler çerçevesinde belirlenebilmektedir (Erbakan, 2019: 83). Fiyatların belirlenme konusunda Adil Ekonomik Düzende serbest piyasa ekonomisi koşullarına benzer bir yapının hakim olduğu söylenebilir.

Ekonomilerde istikrarlı bir para sisteminin varlığı enflasyonun nedeni olan parasal genişlemeyi denetim altına almakta, gelir dağılımı adaletsizliğini önlemekte ve iktisadi istikrarın temelini oluşturmaktadır. İstikrarlı bir para sistemi ise madeni para rejimi veya altın ve gümüş gibi kıymetli maden karşıllı̆ı olan kağıt para rejimi ile gerçekleştirilmektedir. Ancak son yıllarda ekonominin gittikçe hayali hale gelmiş olduğu görülmektedir. Bunu en önemli çıkış noktası olarak ise kağıt paraların alıın karşılığının ortadan kaldırılması ile kaydi para üretiminin teşvik edilmesi gösterilmektedir (Karaman, Erişim Tarihi: 2.3.2021). Adil Ekonomik Sistemin para=mal ilkesi gereği piyasada var olan paranın muhakkak bir mal karşılığının bulunmasının istikrarlı bir para sisteminin varlığını sağlama konusunda son derece önemli olduğu ve söz konusu ilkenin varlığı ile birlikte ekonomideki yapısal sorunların giderilebileceği görülmektedir. 


\section{Sonuç}

Temelleri 17. yüzyılda İngiltere’de atılan ve modern bankacılık sistemi olarak değerlendirilen kısmi rezerv sistemi, bankaya yatırılan mevduatın sadece bir kısmının bankada tutularak geriye kalan büyük çoğunluğunun ise bankalar tarafından kredi olarak diğer müşterilere verilmesini mümkün kılan sitem olarak tanımlanmaktadır. Kısmi rezerv sistemi ile beraber ticari bankaların ellerindeki mevduatın neredeyse 10 katı kadar para üretmelerine firsat sunulmaktadır. Bankaların bu yolla oluşturdukları ve kaydi para olarak isimlendirilen aslında hayali olarak para üretiminin gerçekleştirildiği bu sistem pek çok ekonomik sorunun da temelini teşkil etmektedir. Türkiye ekonomisi açısından değerlendirildiğinde ise 2020 yılında bankalar tarafından verilen kredi miktarının Merkez Bankası tarafından gerçekleştirilen emisyon miktarından 16 kat, 2021 yılı ise aylar bazında incelendiğinde yaklaşık 19 kat daha fazla olduğu görülmektedir.

Kısmi rezerv sistemine bağlı olarak bankalar tarafından gerçekleştirilen kaydi para oluşumunun ekonomi üzerinde oldukça fazla olumsuz etkisi bulunmaktadır. Bu olumsuz etkilerin başında enflasyon oranlarının çok ciddi seviyelere yükselmesi ve bunun neden olduğu alım gücü kısıtlamaları, akabinde hem iç hem de dış borçlanmaların artması, gelir dağılımı eşitsizliklerinin artış göstermesi gelmektedir. Tüm bu problemler ekonominin istikrarını bozmakta ve ekonomiyi dış rekabete karşı daha zayıf hale getirmektedir. Kısmi Rezerv Sistemine bağlı olarak gerçekleştirilen kaydi para oluşumu ile ekonomide tabiri caizse bir balon oluşmakta ve bu durum da ciddi bir ekonomik krizin habercisi olmaktadır. Kaldı ki 1929 Büyük Buhranda olduğu gibi 2008 Küresel Finansal Krizin nedeni de kısmi rezerv sistemine bağlı gerçekleşen bankacılık faaliyetleridir.

Kısmi rezerv sisteminin ekonomi üzerinde neden olduğu istikrarsızlıklar ve bu istikrarsızlıkların sonucunda toplumda ekonomik ve sosyal anlamda meydana gelen sorunlara çözüm olarak gösterilebilecek sistem, bankaya yatırılan vadesiz mevduatın tamamının bankada tutulması anlamına gelen tam rezerv sistemidir. Bu sisteme göre bankalara yatırılan vadesiz mevduatların tamamının bankada tutulması gerektiği için kısmi rezerv bankacılığında olduğu gibi kaydi para oluşturulması söz konusu değildir.

Bankalar kaydi para oluşturarak kredi verme olanaklarını artırmakta böylece çok ciddi oranlarda faiz geliri elde etmektedirler. Faizi haksız kazanç ve bir sömürü aracı olarak değerlendiren İslam ekonomisi kısmi rezerv sistemi neticesinde ekonomilerde gerçekleşen sorunların temelinin aslında faiz kökenli olduğunu ifade etmektedir. Faize bağlı olarak enflasyon oranlarının artması, borçlanma oranlarının artış göstermesi böylece gelir dağılımının yoksuldan zengine doğru gelir akışının gerçekleşmesi ve buna bağlı olarak da gelir dağılımı eşitsizliklerinin artması sosyal refaha son derece kıymet veren İslam ekonomisi ilkelerine aykırı durmaktadır. Bu sebeple İslam ekonomisinin söz konusu hassasiyetleri göz önünde bulundurulduğunda faizin yer almadığı tam rezerv sistemi kabul görmektedir.

Modern bankacılık sistemi olarak değerlendirilen ve kaydi para oluşumuna zemin hazırlayan kısmi rezerv sisteminin olumsuz sonuçlarının ortadan kalkmasına yönelik olarak tam rezerv sistemine yakın bir çözüm sunan, İslam ekonomisi ilkelerini benimseyen, Türkiye ekonomisine özgü geliştirilmiş olan, para=mal ilkesini savunan Adil Ekonomik Düzen önerilebilir. Bu sistemde para=mal ilkesi gereği üretilen her bir birim paranın bir mal karşılığının bulunması gerekmektedir. Böylece kaydi paranın neden olduğu tüm ekonomik problemlerin çözüme kavuşacağı öngörülmektedir. Devlet borçlarının minimum düzeye inmesi, piyasada para arzı genişlemesi hız keseceği için enflasyon oranlarının gerilemesi, arz edilen her bir birim paranın üretilen mala karşılık gelmesi gerektiği için üretimin artması, ekonomik büyümenin gerçekleşmesi, böylece finansal büyümeden ziyade ekonomilerin arzu ettikleri reel büyümenin gerçekleşmesi beklenmektedir. Ayrıca bu olumlu gelişmeler neticesinde ülke genelinde sosyal refah artı̧ının gerçekleşeceği, yoksulluk oranlarının minimum düzeye gerileyeceği, gelir dağılımı adaletinin sağlanacağı tahmin edilmektedir. Ekonomik anlamda ülkelerin yapısal sorunları olarak değerlendirilen, uzun yıllar kronikleşmiş problemlerin sitem değişikliğine bağlı olarak kendiliğinden çözüme kavuşacağı düşünülmektedir. Toplum açısından bir değerlendirme yapıldığında ise hem ekonomik hem de sosyal açıdan pek çok sorunun çözüme kavuşacağı öngörülmektedir. 


\section{Kaynaklar}

Chapra, M.U. (1985). “Towards A Just Monetary System”, The Islamic Foundation, Leicester, UK.

Chapra, M.U. (1996). “Monetary Management In An Islamic Economy”, Islamic Economic Studies, Vol:4, No:1, $1-35$.

Çizakça, M. (2011). "The Islamic Gold Dinar-Myths And Reality", ISRA International Journal of Islamic Finance, Volume:3, Issue:1.

Diwany, T. E. (2011). Faiz Sorunu. (Çev: Mehmet Saraç), 2. Baskı, İz Yayıncılık, İstanbul.

Dyson, B., Greenham, T. Ryan-Collins, J. \& Werner, R.A. (2010). "Towards A Twenty-First Century Banking And Monetary System", Joint Submission To The Independent Commission On Banking, Centre For Banking, Finance and Sustainable Development, The New Economics Foundation, Positive Money.

Erbakan, N. (2019). Yeni Bir Dünya ve Adil Düzen. (5. Baskı), MGV Yayınları, Ankara.

Erbakan, N. (1991). Adil Ekonomik Düzen. Dergah Yayınları, Ankara.

Ersin, İ. ve Yıldırım, C. (2015). İslam Ekonomisi Çerçevesinde Necmettin Erbakan'ın Adil Düzen Söylemi. AİBÜ Sosyal Bilimler Enstitüsü Dergisi, Cilt:15, Yıl:15, Sayı:1, 15: 143-173

Eskicioğlu, O. (2009). Kitap ve Sünnette Temel İktisadi Kavramlar Adlı Tebliğin Müzakeresi. http://www.enfal.de/oe83.htm, Erişim Tarihi: 22.06.2021.

Ferguson, N. (2020), "Paranın Yükselişi Dünyanın Finansal Tarihi”, (Çeviren: Barış Pala), 8. Baskı, Yapı Kredi Yayınları, İstanbul.

Fisher, I. (1935). “100\% Money”, Adelphi Company, New York.

Goodhart, C. \& Jensen, M. (2015). "Currency School Versus Banking School: An Ongoing Confrontation", Economic Thought, 4 (2), 20-31.

Greco, T.H. (2001). "Money Understanding and Creating Alternatives to Legal Tender", E-book Excerpted Version, Chelsea Green Publishing Company, White River Junction, Vermont.

Huerta D. S. (2020). "Money, Bank Credit and Economic Cycles", (Translate: Melinda Stroup), Fourth English Edition, Mises Institute, Alabama.

Jaffar, S., Abdullah, A. \& Meera, A.K.M. (2017). "Fiat Money: From The Current Islamic Finance Scholars' Perspective", Humanomics, Vol. 33 No. 3, 274-299.

Javaid, O. (2017). "Historical And Ideological Particularity Of The Monetary Institutions: A Comparison Of Islamic And Austrian School's Perspectives", Written for Workshop on the Islamic Monetary Economics and Institutions: Theory and Practice 2017 (1st and 2nd Nov), 1-20.

Karaman, H. "Adil Düzen Değerlendirmeleri ve Cevaplarımı", (Erişim Tarihi: 2.3.2021). https://www.akevler.org/AkevlerKitaplar/1360/74/13-ALTERNATIF-ADIL-DUZEN-14-ILIMADAMININMUSTEREK-TEKLIFI-Hayrettin-Karamanin-ADIL-DUZEN-DEGERLENDIRMELERIVE-CEVAPLARIMIZ.

Lerner, A.P. (1947). "Money as a Creature of the State", The American Economic Review, Vol. 37, No. 2, Papers and Proceedings of the Fifty-ninth Annual Meeting of the American Economic Association, 312-317.

Mevdudi, E.A. (2016). İslam Ekonomisinin Temel İlkeleri. Çıra Yayınları. İstanbul.

Mises, L.V. (1953). “The Theory of Money And Credit”, (Translate From The German By J.E. Batson), Yale University Press.

Mishkin, F.S. (2007). "Para, Bankacılık ve Finansal Piyasalar İktisadı”, Sekizinci Baskıdan Çeviri (Çeviri Ed. Nazım Engin), Akademi Yayıncılık. 
Öztürk, M. (2017). “Adil Ekonomik Düzen’ de Artı(k) Değerin Paylaşımı”, Journal of Turkish Studies, Vol. 12 No. 8, 149-170.

Rothbard, M.N. (2001). "The Case For A 100 Percent Gold Dollar”, The Ludwig von Mises Institute, Alabama.

Sarıbaş, H. ve Yumuşak, İ.G. (2020). “The Just Economic System: A Model and Its Simulations”, International Journal of Islamic and Middle Eastern Finance and Management, Vol. 14 No. 2, 317-338.

Shapiee, R. \& Zahid, A. (2014). “Addressing Economic Meltdown: An Evaluation Of Fiat And Credit Money From Islamic Perspective”, US-China Law Review, Volume: 11, Number:2, 182-202.

Sugözü, İ.H. (2017). "İslam Ekonomisi ve Adil Ekonomik Düzen”, Turkish Studies -International Periodical for the Languages, Literature and History of Turkish or Turkic, Volume 12/8, 185-210.

Yılmaz, E. (2020). “Parayı Kim Yaratır?”, Vergi Dünyası, Y11:39, Sayı: 466, 50-65.

Zaman, A. (2015). "An Islamic Version of the Iceland Plan for Monetary Reform" Conference on "Advancements in Islamic Finance and Business in the 21st Century", on April 24-25, 2015, organized by FAST-NUCES, on Islamabad Campus of National University of Computers \& Emerging Sciences [NUCES], Available at SSRN:. https://ssrn.com/abstract=2593863

Bankacılık Düzenleme ve Denetleme Kurumu (BDDK), http://www.bddk.org.tr/BultenAylik/tr/Home/Gelismis, Erişim Tarihi: 26.06.2021

Türkiye Cumhuriyeti Merkez Bankası (TCMB), https://evds2.tcmb.gov.tr/index.php?/evds/serieMarket, Erişim Tarihi: 26.06.2021 